\title{
Indoor Air Pollutants Influenced by Haze and Their Health Impacts on Malaysian students
}

Maher Elbayoumi ${ }^{1 *}$, Nor Azam Ramli ${ }^{2}$, Noor Faizah Fitri Md Yousif ${ }^{2}$, Mohd Rodzi Ismail ${ }^{2}$

${ }^{1}$ Energy and Sustainable Environment Center, School of Engineering, Israa University, Gaza, Palestine.

${ }^{2}$ Environmental Assessment Research, School of Civil Engineering, Engineering Campus, Universiti Sains Malaysia, 14300 Nibong Tebal, Penang, Malaysia

Email: elbayoumimaher@gmail.com

\begin{abstract}
Haze episode is a common transboundary phenomenon affecting Malaysia, with significant impact on air quality. Quantitative information on the influence of haze episodes on several pollutants in the indoor environment is still lacking. Real-time $\mathrm{PM}_{10}, \mathrm{PM}_{2.5}, \mathrm{O}_{3}, \mathrm{TVOC}, \mathrm{CO}$ and $\mathrm{CO}_{2}$ levels were measured in outdoor and indoor air before and during smoke-haze event in 2013. The analysis revealed a significant contribution of haze event to the indoor PM levels. The average mass concentration of indoor PM 2.5 was increased by a factor of 4 during the smoke-haze period $\left(30.04 \mu \mathrm{g} / \mathrm{m}^{3}\right)$ as compared to non-smoke-haze period $\left(6.89 \mu \mathrm{g} / \mathrm{m}^{3}\right)$, exceeding the WHO guideline's values $\left(25 \mu \mathrm{g} / \mathrm{m}^{3}\right)$. The results show a high contribution of haze episode, with respect to $P M_{2.5}$ and $P M_{10}$ concentrations, where the average indoor and outdoor ratios $\left(P M_{2.5} / P_{10}\right)$ during haze events were 0.66 and 0.70 , respectively. The results serve to improve our understanding of haze episode, pushing us to improve indoor quality.
\end{abstract}

Keywords: Haze episode, Indoor air quality, Outdoor air quality, School Children, PM2.5, PM10, Health symptoms. 
Volume4 : Issue 1, October, 2020

\section{Introduction}

Haze or smoke haze is traditionally an atmospheric phenomenon in which dust, smoke, and other dry particulates obscure the clarity of the sky. Smoke-haze episodes that result from burning of peat soil and plant residue in Sumatra, Indonesia have played an increasingly more pronounced physical and chemical role in air quality of Southeast Asia (SEA) (Sahani et al., 2014). During haze days, the concentration of particulate matter $\left(\mathrm{PM}_{2.5}\right)$, sulphur dioxide $\left(\mathrm{SO}_{2}\right)$, nitrogen dioxide $\left(\mathrm{NO}_{2}\right)$, carbon monoxide $(\mathrm{CO})$, and ozone $\left(\mathrm{O}_{3}\right)$ was found to be higher when compared to non-haze day concentrations ( Afroz et al., 2003; Anwar et al., 2010). The resultant particulate emissions undergo trans-boundary transportation, and are transformed into regional smoke-haze episodes affecting several neighbouring countries in most notably Singapore, Malaysia, Indonesia, and Thailand ( Reid et al., 2013;Behera et al., 2014). According to Pavagadhi et al. (2013), in Singapore during haze episode in 2010, the average mass concentration of $\mathrm{PM}_{2.5}$ increased by a factor of 4 during the smoke haze period $\left(107.2 \mu \mathrm{g} / \mathrm{m}^{3}\right)$, as compared to that during the non-smoke haze period $\left(27.0 \mu \mathrm{g} / \mathrm{m}^{3}\right)$.

Several studies have shown that SEA haze can affect the atmospheric visibility (Hashim et al., 1997; Xu et al., 2014), climate change (Jacobson, 2004), water budget (Sundarambal et al., 2010) and outdoor activities, especially in school and airport closures (Nichol, 1998) and increased amount of economic losses suffered by countries in the region (Afroz et al., 2003). Such studies have also shown that SEA haze, particularly during haze episodes, can have a marked effect on human health, causing, for instance, asthma, eye-associated illnesses, and cardiovascular mortality (Nichol, 1998, Othman et al., 2014). Epidemiological studies in SEA have shown associations between haze aerosols and adverse health outcomes, including increases in the number of emergency room visits (Emmanuel, 2000, Othman et al., 2014), acute childhood asthma (Chew et al., 1995), difficulty breathing time (Sillanpää et al., 2005), child mortality (Jayachandran, 2009), and cancer (Betha et al., 2013). An investigation of the effects of the 1997-haze episode in daily natural mortality in Kuala Lumpur hospitals revealed sharp increases in asthma, an acute 
Volume4 : Issue 1, October, 2020

respiratory infection and increased outpatient attendance between $100 \%$ and $200 \%$ (Othman et al., 2014).

A major gap in our understanding of SEA haze is its impact on indoor environments, particularly schools where students spend seven or more hours a day inside school buildings. Several studies showed that indoor environmental quality at schools is more serious than in other categories of buildings due to inadequate ventilation, insufficiently and infrequently cleaning of indoor surfaces, a higher occupant density per classroom volume, and constant resuspension of particlulates from room surfaces due to the activity of students (Janssen et al., 1999, Pegas et al., 2010; Elbayoumi et al., 2013; Hassanvand et al., 2014).

Malaysia currently is experiencing severe problems in air quality existing in urban areas, resulting from land-use and industrial activities. The main pollutants recorded at the monitoring stations used in Malaysia are: particulate matter $\left(\mathrm{PM}_{10}\right)$, nitrogen dioxide $\left(\mathrm{NO}_{2}\right)$, sulphur dioxide $\left(\mathrm{SO}_{2}\right)$, carbon monoxide $(\mathrm{CO})$, carbon dioxide $\left(\mathrm{CO}_{2}\right)$, and ozone $\left(\mathrm{O}_{3}\right)$ (Azmi et al., 2010). As a tropical country, the lower ventilation rates, combining with increasing the outdoor pollutants, may affect the indoor air quality ( Siti \& Baba 2010). Some indoor air quality (IAQ) studies reported that IAQ, thermal comfort and building-related illnesses (BRI) have become a common issue in Malaysian buildings (Mustapha et al., 2008; Syazwan Aizat et al., 2009; Makhtar et al.; 2010; Kamaruzzaman and Razak, 2011; Norhidayah et al., 2013; Abidin et al., 2014). . However, there is not much literature that specifically addresses IAQ in school buildings (Ismail et al., 2010; Latif et al., 2014; Razali et al., 2015). Research is particularly needed to investigate the deteriorating (IAQ) posed by reducing biomass burning in SEA. This paper explores the impact of outdoor pollutants on IAQ and students health through analyses of real-time data collected from school buildings during a smoke-haze episode and non-haze periods, with the aim to identify the factors affecting indoor pollutants' levels. The results of this study aim to provide a better understanding of the influence of smoke-haze phenomenon in indoor air quality at Malaysian 
Volume4 : Issue 1, October, 2020

schools, and to help in developing approaches to monitor outdoor environment, regarding indoor pollutants in the haze episodes.

\section{Study Area, Materials, and Methodology}

\section{Study area}

Nibong Tebal is a town, which situated in Seberang Perai on the mainland side of Penang, Malaysia between longitudes $5^{\circ} 9^{\prime} 57^{\prime \prime} \mathrm{N}$ and $100^{\circ} 28^{\prime} 40^{\prime \prime} \mathrm{E}$. The town has rapidly developing activities, such as housing, commercial, industrial, and so forth. The major pollutant sources of the surrounding atmospheric environment are industrial and vehicle emissions. Nibong Tebal has tropical climate which is quite uniform throughout the year. According to Malaysian Metrological Department (MMD) the characteristic features of the climate of Malaysia is abundant rainfall and high humidity associated with a low diurnal range, relatively high air temperature throughout the year and wind is generally light (MMD, 2013). IAQ sampling was conducted in two schools (three floor-buildings), located near a main road in in the vicinity of Nibong Tebal as illustrated in Figure 1. The description of the characteristics of monitoring schools and classroom information are presented in Table 1. There are no central air conditioning ventilation systems inside the monitored classrooms. However in each classroom three ceiling fans are installed. 
Volume4 : Issue 1, October, 2020

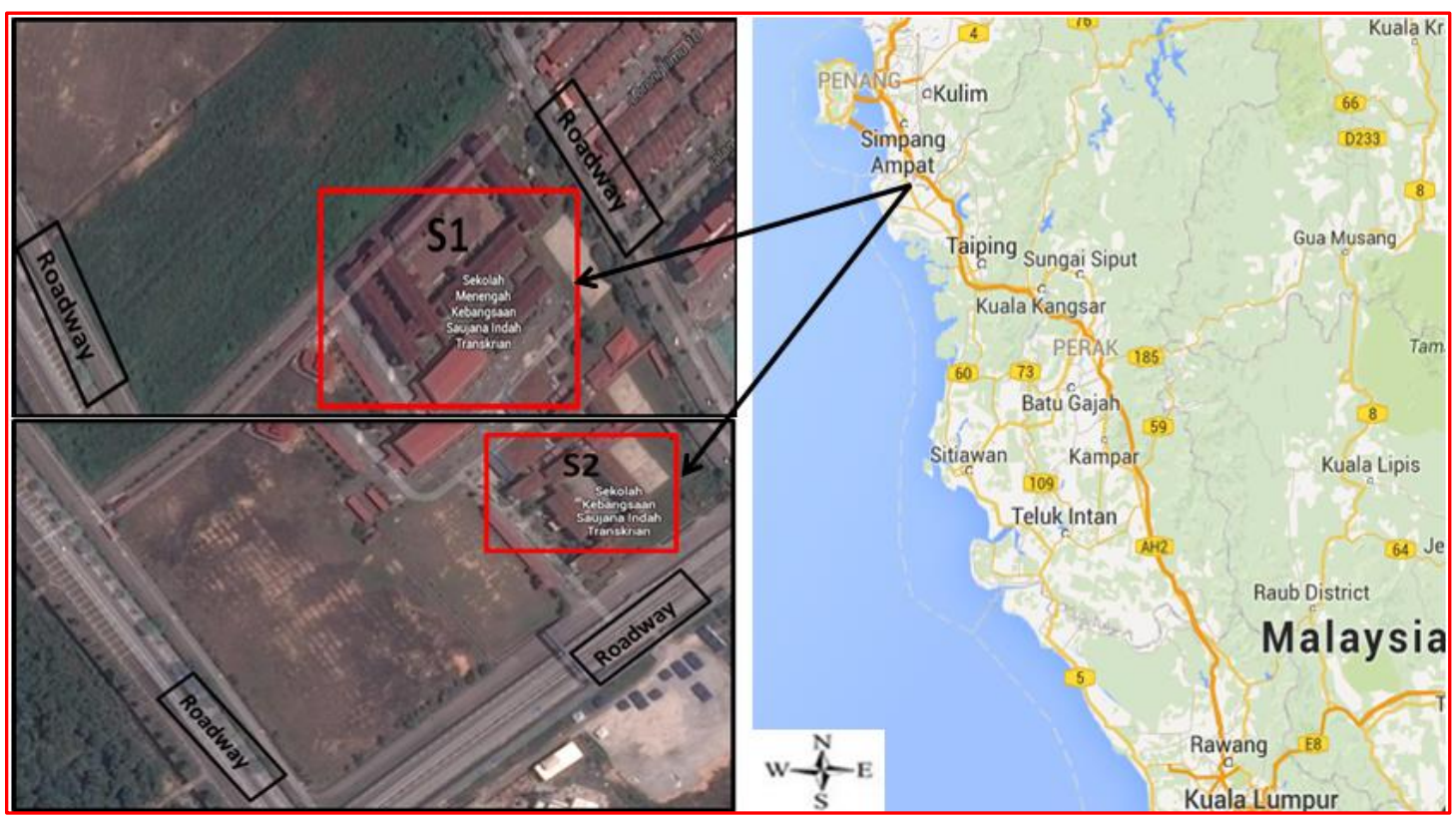

Figure 1: Map of Nibong Tebal and the monitored schools (map is not up to scale)

Table 1: Characteristics of monitored schools in the study area

\begin{tabular}{|c|c|c|c|c|c|}
\hline School & $\begin{array}{l}\text { Number } \\
\text { of } \\
\text { students }\end{array}$ & $\begin{array}{l}\text { Distance } \\
\text { from main } \\
\text { road } \\
(\mathrm{m})\end{array}$ & $\begin{array}{l}\text { Room } \\
\text { area } \\
\left(\mathrm{m}^{2}\right)\end{array}$ & $\begin{array}{l}\text { Windows } \\
\text { area }\left(\mathrm{m}^{2}\right)\end{array}$ & $\begin{array}{l}\text { Windows } \\
\text { type }\end{array}$ \\
\hline $\mathrm{S} 1$ & 713 & 500 & 63 & 21.5 & $\begin{array}{l}\text { Louvre } \\
\text { ( jalousie }) \\
\text { windows }\end{array}$ \\
\hline $\mathrm{S} 2$ & 704 & 250 & 63 & 21.5 & $\begin{array}{l}\text { Louvre } \\
\text { ( jalousie ) } \\
\text { windows }\end{array}$ \\
\hline
\end{tabular}

\section{Instruments}

Indoor and outdoor $\mathrm{PM}_{10}$ and $\mathrm{PM}_{2.5}$ mass concentrations were monitored using real time dust monitoring devices (Met One Inc E-SAMPLER-9800TSI) that recorded simultaneous $\mathrm{PM}_{10}$ and $\mathrm{PM}_{2.5}$ data with a flow rate of $2 \mathrm{~L} / \mathrm{min}$. The monitoring system performs particulate-size measurements by using laser light scattering method. The coarse particulate fraction (i.e. $\mathrm{PM}_{2.5-10}$ ) was calculated by subtracting the $\mathrm{PM}_{2.5}$ fraction from the $\mathrm{PM}_{10}$ value. The devices were operated at each indoor and outdoor measurement point, during which the PM concentrations were recorded 
Volume4 : Issue 1, October, 2020

at 1-min intervals. For measuring the other pollutants $\mathrm{CO}, \mathrm{CO}_{2}, \mathrm{O}_{3}$ and TVOC, the Gray Wolf Sensing Solutions - Model IQ-610 - for IAQ monitoring was used. The sensors exhibit $90 \%$ responses within less than $1 \mathrm{~min}$. Meteorological parameters (temperature, humidity, atmospheric pressure, wind speed and direction) were automatically collected using E-SAMPLER-9800TSI.

\section{Real-time Pollutants measurements}

The study of IAQ at the schools was conducted in three representative classrooms where one classroom was selected from each floor of the school building. Non-haze days (background) readings of indoor and outdoor pollutants were obtained during the haze free-period (May 2013 to June 2013). The haze-free monitoring period was conducted in two phases, background period, as there were no students during the school's holiday (semester break), and the second phase was conducted in the normal schools days (background period in the presence of students). Another set of data was obtained from the same classrooms during haze events (July 2013 to August 2013). The measurements were undertaken in each site during schools hours from 6:30 am to 2:00 $\mathrm{pm}$. The sampling procedure was conducted both inside and outside the selected classrooms during the school activities. The samplers were placed inside the classrooms opposite to the blackboard - at least $1 \mathrm{~m}$ away from the wall and at $1.5 \mathrm{~m}$ height from the floor (Blondeau et al., 2005;WHO, 2011). For outdoor sampling the samplers were placed at the front side of the school building; near the playground area.

\section{Questionnaire}

An adapted version of MM06 School Questionnaire (SQ) was used to measure the occupant perception towards their health symptoms that students complain about (Andersson, 1998). The SQ is a validated self-administered questionnaire designed for the epidemiological assessment of IAQ and sick building symptoms (SBS), and has been widely used in different studies (Nordström et al., 1994, Mizoue et al., 2001). The first part of the SQ was devoted to demographic data, and the rest of it addressed comfort and health-related complaints. 
Volume4 : Issue 1, October, 2020

The following groups of symptoms were considered, (1) Mucosal irritation or upper respiratory problems (dry, itching, irritated, or watery eyes; nasal problems, sore throat, and cough); (2) Lower respiratory problems (tight chest, breathing difficulties, such as breath shortness, and wheeze); (3) Injuries in central nervous system (CNS) (fatigue, headache, heavy head, dizziness, and concentration difficulties); and (4) Dermal symptoms (dry skin, namely in hands) (Madureira et al., 2009). The SQ was distributed during non- haze events for amongst 130 students, and repeated at the same classrooms during haze events for amongst a random sample of 130 students. In total, the fraction of the responding students was $70 \%$ in the baseline and follow-up questionnaire. The characteristics of the participants were $54.4 \%$ girls; $53.3 \%$ in the 3rd level storey of the school building; $25.5 \%$ in the 2 nd level storey; and the average age was 14 years, with the range of 13-15 years of age.

\section{Statistical analysis}

Means and standard deviations were calculated with the aim to describe the dependent and independent variables under background conditions and during the haze events. The Pearson Correlation Matrix of all data was obtained to assess the measure of pair wise association amongst the various variables. Further, $t$ test was used to determine if the two sets of data (for the two schools) were significantly different from each other.

\section{Indoor-outdoor particulates' ratio (I/O)}

The indoor-outdoor particulates' ratio $(\mathrm{I} / \mathrm{O})$ is a common and very easy parameter to to represents the relationship between indoor and outdoor pollutant concentrations. The characteristics of the values of this ratio behave similarly to correlation coefficients (Chen and Zhao, 2011). Thus, I/O ratio data for PMs and gasses pollutants were summarized in order to provide a general impression on the relationship between indoor and outdoor concentrations of the studied variables. The $\mathrm{I} / \mathrm{O}$ ratio is defined as:

$\mathrm{I} / \mathrm{O}=C_{\text {in }} / C_{\text {out }}$ 
Volume4 : Issue 1, October, 2020

where $C_{\text {in }}$ is the indoor concentration and $C_{\text {out }}$ is the outdoor concentration (Chen and Zhao, 2011). Several studies, such as Razali et al. (2015) and Zhao et al. (2015), used this method for similar purposes.

\section{Results and Discussion}

\section{Characteristics of indoor and outdoor pollutants levels}

The PMs $\left(\mathrm{PM}_{2.5-10}\right.$, and $\left.\mathrm{PM}_{2.5}\right)$, gas $\left(\mathrm{O}_{3}\right.$, TVOC, $\mathrm{CO}$ and $\left.\mathrm{CO}_{2}\right)$ and meteorological variables (relative humidity (RH), temperature, and wind speed (WS)) recorded in the classrooms at selected schools are presented in Table 2. The average concentrations of indoor $\mathrm{PM}_{2.5-10}$ and $\mathrm{PM}_{2.5}$ during the school times were $7.26 \pm 5.83 \mu \mathrm{g} / \mathrm{m}^{3}$ and $9.54 \pm 9.51 \mu \mathrm{g} / \mathrm{m}^{3}$, respectively. Meanwhile, outdoor concentration for $\mathrm{PM}_{2.5-10}$ and $\mathrm{PM}_{2.5}$ were $6.48 \pm 4.93 \mu \mathrm{g} / \mathrm{m}^{3}$ and $8.24 \pm 8.49 \mu \mathrm{g} / \mathrm{m}^{3}$, respectively.

Table 2: Summary of the results of the outdoor and indoor measurements during the hazefree event (background) and haze event

\begin{tabular}{|c|c|c|c|}
\hline & $\begin{array}{l}\text { Background event } \\
\text { with no students }\end{array}$ & $\begin{array}{l}\text { Background event } \\
\text { with students }\end{array}$ & Haze event \\
\hline $\begin{array}{l}\mathrm{PM}_{2.5-10} \text { (in) } \\
\left(\mu \mathrm{g} / \mathrm{m}^{3}\right)\end{array}$ & $4.90 \pm 3.74$ & $6.61 \pm 3.84$ & $16.97 \pm 8.29$ \\
\hline $\begin{array}{l}\mathrm{PM}_{2.5-10} \text { (out) } \\
\left(\mu \mathrm{g} / \mathrm{m}^{3}\right)\end{array}$ & $5.52 \pm 3.63$ & $5.58 \pm 4.25$ & $12.97 \pm 6.57$ \\
\hline $\begin{array}{l}\mathrm{PM}_{2.5} \text { (in) } \\
\left(\mu \mathrm{g} / \mathrm{m}^{3}\right)\end{array}$ & $4.86 \pm 2.44$ & $8.93 \pm 6.70$ & $30.04 \pm 7.82$ \\
\hline $\begin{array}{l}\mathrm{PM}_{2.5} \text { (out) } \\
\left(\mu \mathrm{g} / \mathrm{m}^{3}\right)\end{array}$ & $4.56 \pm 2.35$ & $6.54 \pm 4.95$ & $28.07 \pm 4.66$ \\
\hline $\begin{array}{l}\text { TVOC(in) } \\
\text { (ppm) }\end{array}$ & $0.91 \pm 0.31$ & $0.87 \pm 0.32$ & $1.03 \pm 0.25$ \\
\hline $\begin{array}{l}\text { TVOC (out) } \\
\text { (ppm) }\end{array}$ & $0.99 \pm 0.41$ & $0.99 \pm 0.44$ & $1.01 \pm 0.32$ \\
\hline $\mathrm{O}_{3}$ (in) (ppm) & $0.01 \pm 0.01$ & $0.01 \pm 0.01$ & $0.02 \pm 0.01$ \\
\hline $\begin{array}{l}\mathrm{O}_{3} \text { (out) } \\
(\mathrm{ppm})\end{array}$ & $0.01 \pm 0.01$ & $0.01 \pm 0.01$ & $0.02 \pm 0.01$ \\
\hline $\begin{array}{l}\mathrm{CO}(\mathrm{in}) \\
\text { (ppm) }\end{array}$ & $0.05 \pm 0.12$ & $0.05 \pm 0.12$ & $0.09 \pm 0.12$ \\
\hline $\begin{array}{l}\text { CO (out) } \\
\text { (ppm) }\end{array}$ & $0.09 \pm 0.18$ & $0.11 \pm 0.20$ & $0.05 \pm 0.09$ \\
\hline $\begin{array}{l}\mathrm{CO}_{2} \text { (in) } \\
(\mathrm{ppm})\end{array}$ & $472.83 \pm 5.88$ & $514.57 \pm 53.30$ & $552.89 \pm 87.10$ \\
\hline $\begin{array}{l}\mathrm{CO}_{2} \text { (out) } \\
(\mathrm{ppm})\end{array}$ & $472.83 \pm 5.88$ & $477.11 \pm 45.77$ & $471.38 \pm 25.84$ \\
\hline RH(in) & $64.13 \pm 7.31$ & $70.66 \pm 6.74$ & $75.99 \pm 6.16$ \\
\hline RH (out) & $64.27 \pm 12.36$ & $71.04 \pm 9.34$ & $68.09 \pm 7.00$ \\
\hline
\end{tabular}


Volume4 : Issue 1, October, 2020

\begin{tabular}{|l|c|c|c|}
$\begin{array}{l}\text { Temperature } \\
\left(\text { in) }\left({ }^{\circ} \mathrm{c}\right)\right.\end{array}$ & $32.41 \pm 1.69$ & $29.49 \pm 1.88$ & $29.34 \pm 1.24$ \\
\hline $\begin{array}{l}\text { Temperature } \\
\text { (out) } \\
\left({ }^{\circ} \mathrm{c}\right)\end{array}$ & $32.86 \pm 3.04$ & $29.65 \pm 2.51$ & $30.95 \pm 2.03$ \\
\hline $\mathrm{WS}(\mathrm{m} / \mathrm{s})$ & $0.65 \pm 0.29$ & $0.68 \pm 0.31$ & $0.63 \pm 0.51$ \\
\hline
\end{tabular}

The haze-free period (background with no students) was characterized by a smooth curve with low concentration and the average indoor and outdoor concentration levels of $\mathrm{PM}_{2.5-10}$ and $\mathrm{PM}_{2.5}$ were almost the same as shown in Figure. 2.

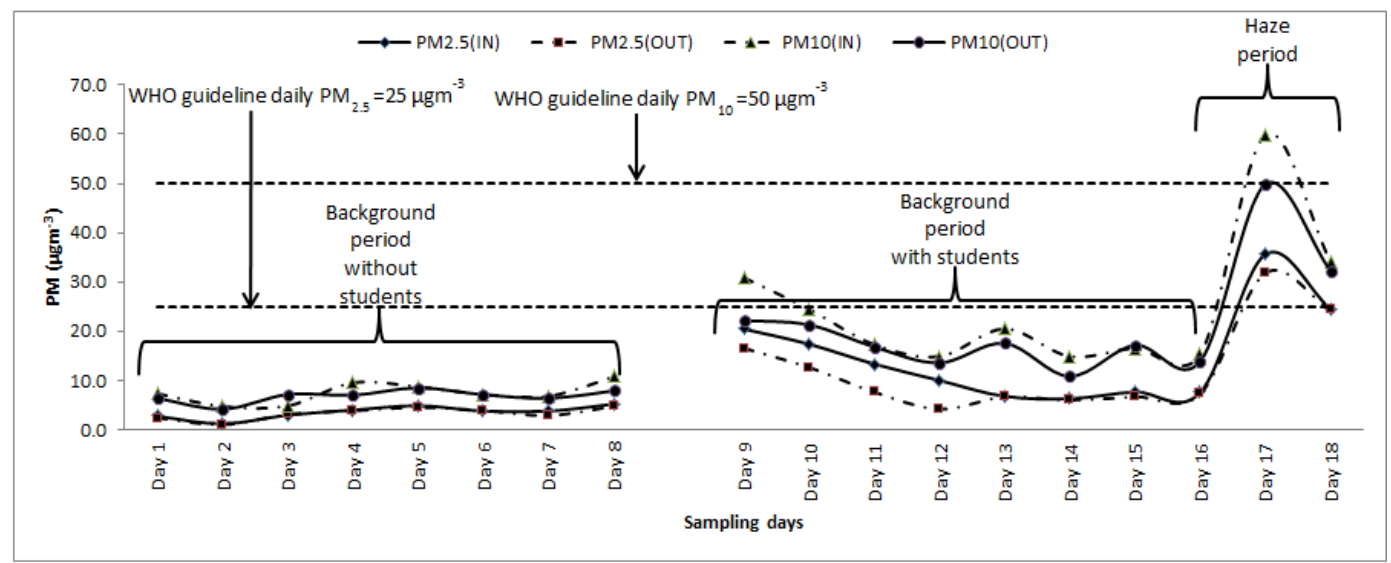

Figure 2: Average daily concentrations of indoor and outdoor $\mathrm{PM}_{10}$ and $\mathrm{PM}_{2.5}$ during three monitoring periods

However, these indoor $\mathrm{PM}_{2.5-10}$ and $\mathrm{PM}_{2.5}$ concentrations were greater than outdoor concentrations which reflect the presence of children inside the classrooms. This was in good agreement with previous studies conducted by Diapouli et al. (2007), and Ismail et al. (2010), which reported that the indoor PMs levels were higher than outdoor ones which due to student's activities, including writing on the blackboard using chalks, erasing chalks using duster- Further, the outdoor concentration of $\mathrm{PM}_{2.5}$ during background event (in the presence of students) was increased, comparing with background event (in the lack of students) which was related to motor-vehicle emissions near the school buildings.

The trend of average recorded concentrations of $\mathrm{PM}_{2.5-10}$ and $\mathrm{PM}_{2.5}$ indoor and outdoor of the classrooms significantly increased during haze event, and $\mathrm{PM}_{2.5}$ concentrations exceeded the values of the WHO guideline $\left(25 \mu \mathrm{g} / \mathrm{m}^{3}\right.$ for $\left.\mathrm{PM}_{2.5}\right)$ (Figure 2). The average concentrations of indoor $\mathrm{PM}_{2.5-10}$ and $\mathrm{PM}_{2.5}$ during the study period were $16.97 \pm 8.29 \mu \mathrm{g} / \mathrm{m}^{3}$ and $30.04 \pm 7.82 \mu \mathrm{g} / \mathrm{m}^{3}$, respectively. Meanwhile, 
Volume4 : Issue 1, October, 2020

outdoor concentration for $\mathrm{PM}_{2.5-10}$ and $\mathrm{PM}_{2.5}$ were $12.97 \pm 6.57 \mu \mathrm{g} / \mathrm{m}^{3}$ and $28.07 \pm 4.66 \mu \mathrm{g} / \mathrm{m}^{3}$, respectively. Thus, the average mass concentration of indoor $\mathrm{PM}_{2.5}$ increased by a factor of 4 during the smoke-haze period $\left(30.04 \mu \mathrm{g} / \mathrm{m}^{3}\right)$, as compared to that during the non-smoke-haze period $\left(6.89 \mu \mathrm{g} / \mathrm{m}^{3}\right)$ which is in agreement with Pavagadhi et al. (2013) study.

In addition, Payus et al. (2013) study revealed that during several haze periods the airborne particulate matter (PM) was found to be the major pollutants that affect Malaysia. A comparison with other studies that conducted worldwide showed that the indoor average concentrations of $\mathrm{PM}_{2.5-10}$ and $\mathrm{PM}_{2.5}$, as obtained in this study, were far lower compared with results obtained from other studies (Razali et al. (2015) in Malaysia; Elbayoumi et al. (2013) in Palestine; Almeida et al. (2011) in Portugal; Habil et al. (2013) and Mathew et al. (2014) in India).

The average concentrations of TVOC, $\mathrm{O}_{3}, \mathrm{CO}$ and $\mathrm{CO}_{2}$ in classrooms were $0.91 \pm 0.30 \mathrm{ppm}, 0.01 \pm 0.08 \mathrm{ppm}, 0.06 \pm 0.12 \mathrm{ppm}$ and $498.40 \pm 51.6 \mathrm{ppm}$, respectively. There were no significant differences between indoor TVOC, $\mathrm{O}_{3}, \mathrm{CO}$ concentrations recorded in the different sampling periods, which are in agreement with Payus et al. (2013) study, which reported that in Malaysia and during several haze periods, $\mathrm{O}_{3}$ and $\mathrm{CO}$ remained within the permissible limits. However, a noticeable significant difference in indoor $\mathrm{CO}_{2}$ concentration was shown during haze event, which is mainly related to the invasion of outdoor source and respiration process of the students inside the classrooms. The average indoor and outdoor TVOC, $\mathrm{O}_{3}, \mathrm{CO}$ and $\mathrm{CO}_{2}$ concentrations for the two schools during the study can be considered low and does not show any significant differences $(p>0.05)$. These values were below the Malaysian Code of Practice (DOSH, 2010). Further, the lower concentration of CO may be due to schools' location as a suburban area, where $\mathrm{CO}$ is considered as a scale pollutant generated by road traffic, and tends to be present at high levels within urban locations and reduced nearby rural areas (WHO, 2005). 
Volume4 : Issue 1, October, 2020

\section{Variation characteristic of PM mass concentrations}

Table 3 shows different indoor and outdoor $\mathrm{PM}_{2.5} / \mathrm{PM}_{10}$ fractions during the three monitoring periods. The average indoor and outdoor $\mathrm{PM}_{2.5} / \mathrm{PM}_{10}$ ratios in classrooms recorded in this study ranged from $0.43 \pm 0.13$ to $0.66 \pm 0.08$ and from $0.47 \pm 0.17$ to $0.70 \pm 0.07$, respectively. This indicates that fine particlulates $(<2.5$ $\mu \mathrm{m} / \mathrm{m}^{3}$ ) are the dominating fraction in particulate matter in the three monitoring periods.

Table 3: Different indoor and outdoor $\mathbf{P M}_{2.5} / \mathbf{P M}_{10}$ fractions during the three monitoring periods

\begin{tabular}{|c|c|c|c|}
\hline Sampling period & & $\begin{array}{l}\text { Indoor } \\
\mathrm{PM}_{2.5} / \mathrm{PM}_{10}\end{array}$ & $\begin{array}{l}\text { Outdoor } \\
\text { PM }_{2.5} / \mathrm{PM}_{10}\end{array}$ \\
\hline \multirow{4}{*}{$\begin{array}{l}\text { Background period } \\
\text { without students }\end{array}$} & Minimum & 0.21 & 0.18 \\
\hline & Maximum & 0.80 & 0.75 \\
\hline & Mean & 0.43 & 0.47 \\
\hline & Std. Deviation & 0.13 & 0.17 \\
\hline \multirow{4}{*}{$\begin{array}{l}\text { Background period } \\
\text { with students }\end{array}$} & Minimum & 0.35 & 0.24 \\
\hline & Maximum & 0.85 & 0.97 \\
\hline & Mean & 0.64 & 0.55 \\
\hline & Std. Deviation & 0.13 & 0.19 \\
\hline \multirow[t]{4}{*}{ Haze event } & Minimum & 0.56 & 0.60 \\
\hline & Maximum & 0.78 & 0.77 \\
\hline & Mean & 0.66 & 0.70 \\
\hline & Std. Deviation & 0.08 & 0.07 \\
\hline
\end{tabular}

The ratios of indoor and outdoor are within WHO's normal range of 0.5-0.8 for developed countries (WHO, 2005). According to Ward (1990) approximately 90\% of soot coming from biomass burning is lower than $2.5 \mu \mathrm{m}$ in size and the remainder lower than $10 \mu \mathrm{m}$. Due to the small size, the soot in the air can be transported over long distances and remain suspended for up to one week, resulting in a regional smoke haze (Pavagadhi et al., 2013).

Taking one hour as the time resolution, the 6-hour period time series of indoor and outdoor PM mass concentrations are presented in Figure 3. It can be seen that the PM2.5-10 and PM2.5 showed a similar pattern of variation, but the magnitudes of 
Volume4 : Issue 1, October, 2020

variations were different. The shapes of PM2.5-10 and PM2.5 cycles are strongly affected by the levels of their sources as well as the meteorological conditions (temperature, humidity, and wind speed). The indoor PM2.5-10 and PM2.5 concentrations follows the trend of outdoor PM and showed stable trend during the three periods. This finding indicates that variations in outdoor sources are important factors influencing indoor PM2.5-10 and PM2.5 levels by infiltration ventilation (Hänninen et al., 2011).

During daytime, weather stability frequently, occurred in the morning hours due to temperature inversions which tend to trap PM in the region, increased the outdoor concentration in the morning. Thus, low atmospheric stability and strong vertical turbulent diffusion can improve atmospheric particulates to diffuse indoor.

PM2.5-10 and PM2.5 concentrations reached a maximum during morning hours in the beginning of the schools in all three periods. The higher concentrations of indoor PMs in the presence of students were probably due to regular cleaning activities and students movements before the beginning of classes.

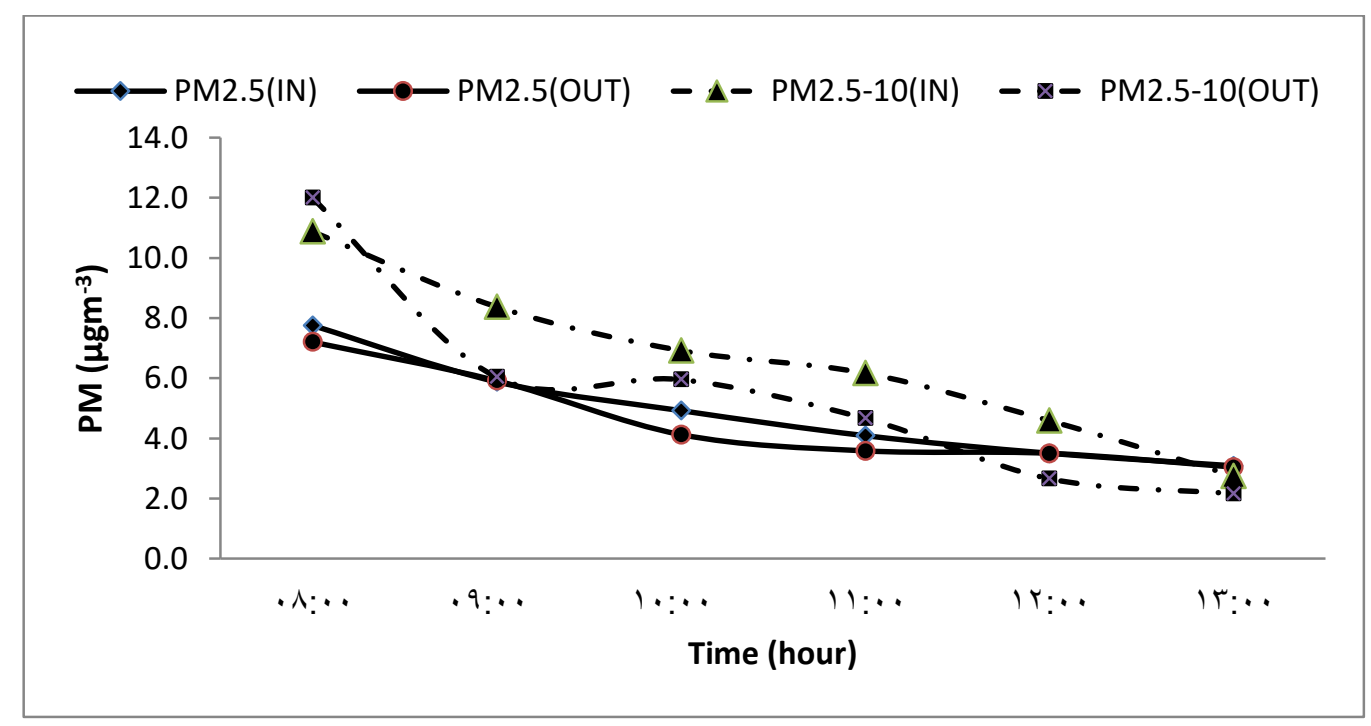

(a) background period without students 
Volume4 : Issue 1, October, 2020

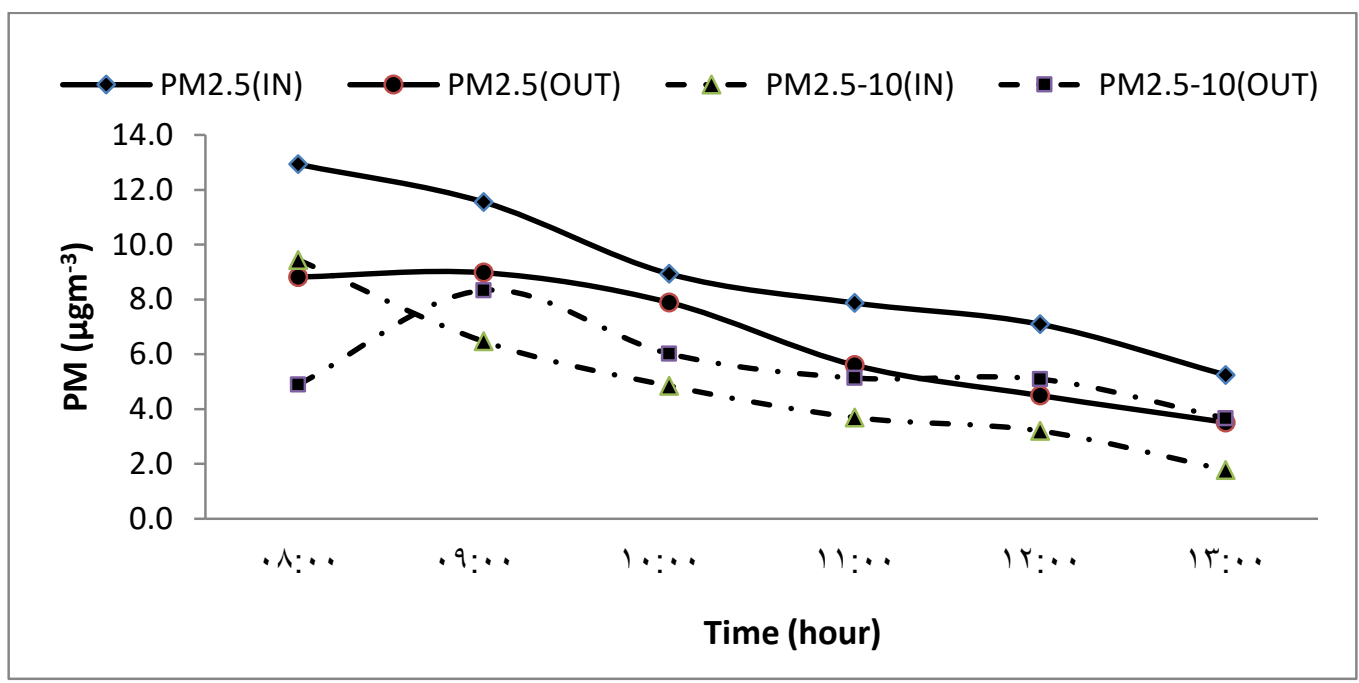

(b) background period with students

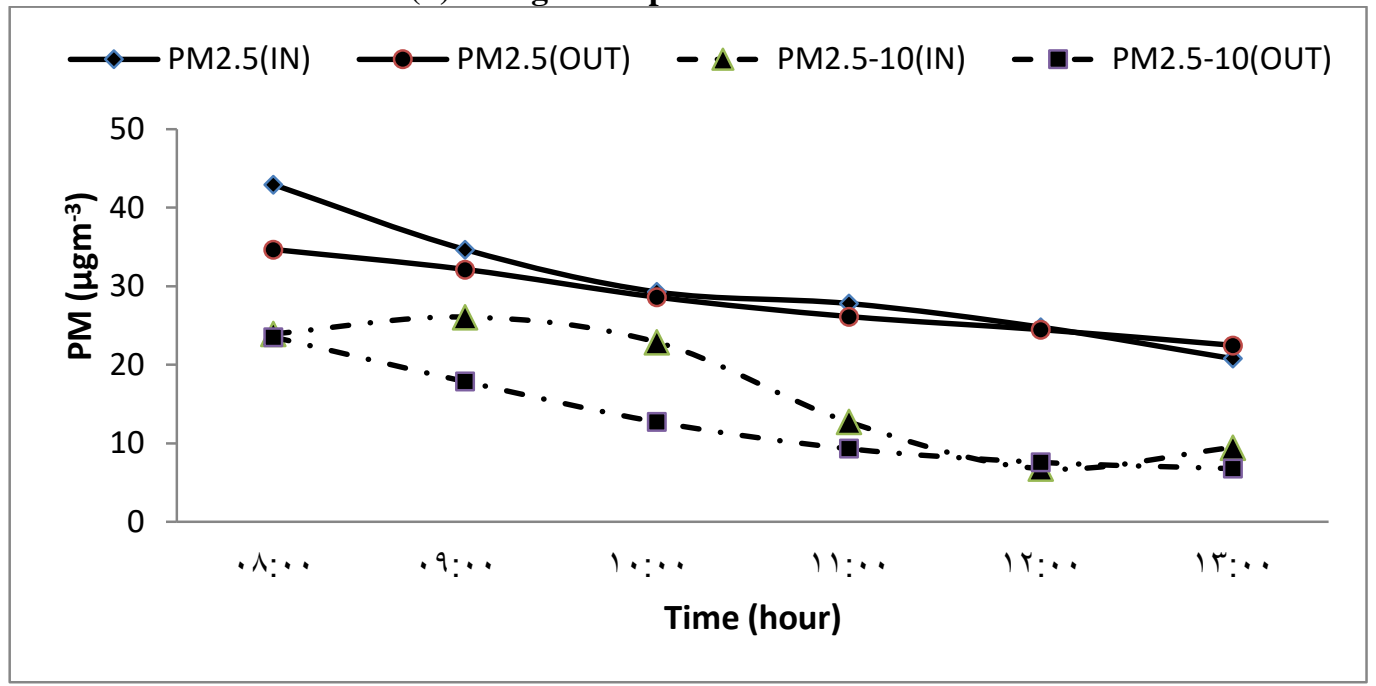

(c) haze event

Figure 3: Six hours (6-hour) time series on indoor and outdoor concentrations of PMs.

Several studies revealed that human activity, such as cleaning (vacuuming, dusting, sweeping) and walking around significantly tend to generate short duration and high concentration particulate events with diameters ranged from 1-10 $\mu \mathrm{m}$ (Abt et al., 2000, Ferro et al., 2004). This can result in elevation of indoor PMs concentrations several times of magnitude above outdoor levels. Increased levels of PMs at the beginning and the end of classes were also reported by some other studies (Hassanvand et al., 2014, Elbayoumi et al., 2015, Razali et al., 2015). Furthermore, after morning peak values, the $\mathrm{PM}_{2.5-10}$ concentration displays a gradual decrease followed by a unimodal pattern peak between 09:00 and 10:00 a.m, which may be 
Volume4 : Issue 1, October, 2020

due to the student's movements inside the classrooms that may promote coarser PMs resuspension or delay the deposition process.

\section{Indoor/outdoor ratios (I/O)}

The I/O ratio can provide a general impression on the relationship between indoor and outdoor concentrations of pollutants; nevertheless, it varies due to many influencing factors such as indoor source, outdoor concentration, air exchange rate, penetration factor and deposition rate (Chen and Zhao, 2011). Average I/O ratio values for 6-hour periods are shown in Figure 4.

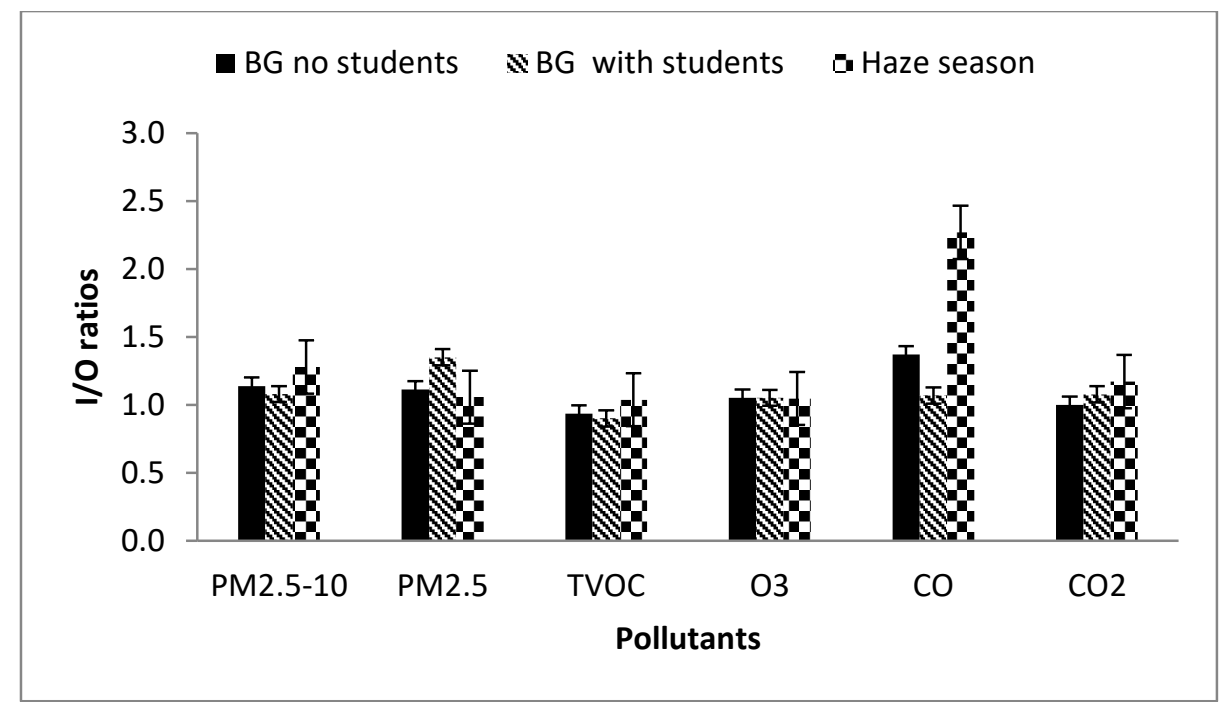

Figure 4: Indoor/Outdoor (I/O) ratio values for six parameters collected from three different periods:

The average daily $\mathrm{I} / \mathrm{O}$ ratio for $\mathrm{PM}_{2.5-10}$ ranged from 1.10 to 1.17 with a mean of 1.35 \pm 0.93 . Furthermore, the mean I/O ratios for $\mathrm{PM}_{2.5}$ ranged from 1.06 to 1.35 with a mean of $1.19 \pm 0.38$. Indeed, several studies revealed that indoor particulate matter concentrations can exceed outdoor air concentrations Zock et al., 2002; (Diette et al., 2007; USEPA, 2012). The results show that the $\mathrm{I} / \mathrm{O}$ ratios of $\mathrm{PM}_{2.5-10}$ are higher than that of $\mathrm{PM}_{2.5}$. The indoor sources may emit more coarse particles than fine particles, while outdoor coarse particle concentration is lower than fine particles, which may cause the lower I/O ratio of $\mathrm{PM}_{2.5}$ than that of $\mathrm{PM}_{2.5-10}$ (Chen and Zhao, 2011). Further, the deposition rate for $\mathrm{PM}_{2.5-10}$ should be larger than that of $\mathrm{PM}_{2.5}$, while penetration factor for $\mathrm{PM}_{10}$ should be smaller than that of $\mathrm{PM}_{2.5}$. 
Volume4 : Issue 1, October, 2020

The characteristics of penetration factor and deposition rate may cause the higher $\mathrm{I} / \mathrm{O}$ ratio of $\mathrm{PM}_{2.5-10}$ than that of $\mathrm{PM}_{2.5}$ during the monitoring periods.

Regarding the pollutants $\mathrm{O}_{3}$ and TVOC, the mean $\mathrm{I} / \mathrm{O}$ ratios were $1.05 \pm 0.20$ and $0.93 \pm 0.11$ respectively. Since there are no sources of $\mathrm{O}_{3}$ and TVOC originated inside the classrooms, $\mathrm{O}_{3}$ and the TVOC found indoor were mainly derived from outdoor. For CO pollutant, the average I/O ratio was $1.37 \pm 1.64$. However, this ratio varied significantly during the three monitoring periods and ranged from 1.07 (background) to 2.27 (haze).

\section{Factors affecting indoor pollutants levels}

Bivariate correlations were carried out to view the dependency of indoor particulates on their corresponding outdoor ones and meteorological parameters, as presented in Table 4. The overall relationships between the indoor variables investigated at all periods were significant at define $\mathrm{p} p<0.01$. The results indicate that outdoor PMs are the dominant factor controlling indoor PMs during haze and non-haze events. Stronger correlation between indoor $\mathrm{PM}_{25}, \mathrm{PM}_{2.5-10}$ and outdoor concentrations was found on the haze days (Pearson correlation coefficient: 0.97 and 0.85 , respectively) compared to background days (in the presence of students) (Pearson correlation coefficient: 0.92 and 0.33, respectively). Furthermore, a positive and significant correlations between indoor and outdoor PMs and TVOC and $\mathrm{CO}$ were shown in Table 4, which may be due to combustion processes, particularly originating from motor vehicles and industrial activities. These correlations observed in this study are consistent with the findings by Dominick et al. (2012) which concluded that air pollutants influence the concentration of PMs. On haze days, and background with schooling periods, $\mathrm{CO}_{2}$ was positively correlated with the indoor PMs concentration. The finding, however, shows an inverse correlation with indoor PMs on background days (in the presence of students). A study by Fromme et al. (2007) also showed a significant positive correlation between indoor $\mathrm{CO}_{2}$ and indoor PMs concentration, which may be attributed to the presence of students and their related activities that influence particulates' resuspension. 
Volume4 : Issue 1, October, 2020

In addition to that, a strong and robust correlation coefficient was obtained between indoor TVOC and outdoor levels (Pearson correlation coefficient 0.93, 0.95 and 0.97 background-no students, background-with students and haze, respectively), as presented in Table 4. Similarly, to TVOC, indoor $\mathrm{O}_{3}$ showed a consistently strong to moderate positive relationship ( $\mathrm{r}=0.88,0.96$ and 0.78 ) with outdoor $\mathrm{O}_{3}$ in background- no schooling period, background period in the presence of students, with students period and haze period, respectively. The relationship between environmental pollutants data and meteorological parameters, such as temperature, relative humidity, and wind speed is examined, as depicted in Table 4. There was a positive relationship between relative humidity and PMs, TVOC and CO and a negative relationship with $\mathrm{CO}_{2}$ and $\mathrm{O}_{3}$ during background periods. Similar studies reported a positive relationship between relative humidity and indoor pollutants concentrations (Fromme et al., 2007, Alshitawi et al., 2009). Temperature (T) showed a negative relationship with PMs, which can be explained by the mixing height factor. High temperatures increase evaporation processes as well as increase the mixing height, and, as a result, the dispersion rate of surface pollutants towards the upper part of the atmospheres increase and reduces the pollutants concentration (Razali et al., 2015). Similarly, as temperature, wind speed showed a negative and significant correlation with monitoring pollutants. A high wind speed enhances pollutants dispersion which will decrease their outdoor levels (Chaloulakou and Mavroidis, 2002, Chithra and Nagendra, 2012). 
Volume4 : Issue 1, October, 2020

Table 4: Summary of Correlation coefficient among variables during the three sampling periods.

\begin{tabular}{|c|c|c|c|c|c|c|c|c|c|c|c|c|c|c|c|c|c|}
\hline & type & $\begin{array}{l}\mathrm{PM}_{25} \\
\text { (out) }\end{array}$ & $\begin{array}{l}\mathrm{PM} 25-10 \\
\text { (in) }\end{array}$ & $\begin{array}{c}\mathrm{PM}_{2 \leq 10} \\
\text { (out) }\end{array}$ & $\begin{array}{l}\text { TVOC } \\
\text { (in) }\end{array}$ & $\begin{array}{l}\text { TVOC } \\
\text { (out) }\end{array}$ & $\begin{array}{l}\mathrm{CO}_{2} \\
\text { (in) }\end{array}$ & $\begin{array}{l}\mathrm{CO}_{2} \\
\text { (out) }\end{array}$ & $\begin{array}{l}\mathrm{O}_{3} \\
\text { (in) }\end{array}$ & $\begin{array}{c}0_{3} \\
\text { (out) }\end{array}$ & $\begin{array}{l}\mathrm{CO} \\
\text { (in) }\end{array}$ & $\begin{array}{c}\mathrm{CO} \\
\text { (out) }\end{array}$ & $\begin{array}{l}\mathrm{RH} \\
\text { (in) }\end{array}$ & $\begin{array}{c}\mathrm{RH} \\
\text { (out) }\end{array}$ & $\begin{array}{l}\text { Temp } \\
\text { (ii) }\end{array}$ & $\begin{array}{l}\text { Temp } \\
\text { (out) }\end{array}$ & WS \\
\hline \multirow{12}{*}{ 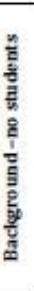 } & $\mathrm{PM}_{2 \mathrm{~s}}$ (in) & $0.96^{4}$ & $0.74^{\prime \prime}$ & $0.73^{\prime \prime}$ & $0.76^{*}$ & $0.74^{* *}$ & $-0.49^{\circ}$ & $-0.49^{\circ}$ & -0.27 & -0.26 & 0.22 & 0.21 & $0.49^{\circ}$ & $0.54^{*}$ & $-51^{-}$ & $.45^{\circ}$ &,$- 56^{\prime \prime}$ \\
\hline & $\mathrm{PM}_{2 \mathrm{~S}}$ (out) & 1.00 & $0.73^{\prime \prime}$ & $0.67^{*}$ & $0.77^{\mathrm{m}}$ & $0.75^{\prime \prime}$ & $-0,49^{\circ}$ & $-0.49^{\circ}$ & -0.26 & -0.25 & 0.20 & 0.26 & $0.49^{\circ}$ & $0.56^{\prime \prime}$ & $-0.51^{*}$ & $-0.44^{*}$ & $-0.61^{\prime \prime}$ \\
\hline & $\mathrm{PM}_{2510}$ (in) & & 1.00 & $0.87^{-*}$ & $0.78^{\prime \prime}$ & $0.85^{\prime \prime}$ & $-0,48^{\circ}$ & $-0.48^{\circ}$ & -0.34 & -0.33 & -0.01 & 0.40 & $0.60^{\prime \prime \prime}$ & $0.63^{--}$ & $-0.56^{\prime \prime}$ & $-0.55^{\prime \prime}$ & $-0,42^{*}$ \\
\hline & PM/2-10 (out) & & & 1.00 & $0.62^{\prime \prime}$ & $0.77^{*}$ & $-0.51^{\prime \prime}$ & $-0.51^{\prime \prime}$ & -0.36 & $-0,38$ & 0.10 & $0.50^{\circ}$ & $0.67^{\circ}$ & $0.70^{\prime \prime}$ & $-0.65^{\prime \prime}$ & $-0.64^{*}$ & $-0,37$ \\
\hline & TVOC (in) & & & & 1.00 & $0.93^{*}$ & $-0.58^{\prime \prime}$ & $-0.58^{\prime \prime}$ & $-0,41^{\circ}$ & -0.39 & $0.41^{\circ}$ & $0.42^{*}$ & $0.54^{* *}$ & $0.55^{-4}$ & $-60^{-\prime}$ & $-0.54^{* \prime}$ & $-0.50^{\circ}$ \\
\hline & TVOC (out) & & & & & 1.00 & $-0.62^{-2}$ & $-0.62^{*}$ & $-0,46^{2}$ & $-0.47^{*}$ & 0.38 & $0.55^{\prime \prime}$ & $0.69^{m+2}$ & $0.73^{\prime \prime}$ & $-0.72^{-m}$ & $-0.70^{\prime \prime}$ & $-0.53^{-1}$ \\
\hline & $\mathrm{CO}_{2}$ (in) & & & & & & 1.00 & $1.00^{\prime \prime}$ & 0.34 & 0.37 & $-0,43^{\circ}$ & $-0.48^{*}$ & $-0.53^{\prime \prime}$ & $-0,64^{-\prime}$ & $0.61^{-1}$ & $0.67^{\prime \prime}$ & 0.40 \\
\hline & $\mathrm{CO}_{2}$ (out) & & & & & & & 1.00 & 0.34 & 0.37 & $-0,43^{\circ}$ & $-0.48^{*}$ & $-0.53^{\prime \prime}$ & $-0.64^{-\prime}$ & $0.61^{-1}$ & $0.67^{\prime \prime}$ & 0.40 \\
\hline & $0_{3}$ (in) & & & & & & & & 1.00 & $0.88^{-\prime}$ & -0.23 & -0.28 & $.637^{\prime \prime}$ & $-0.46^{\circ}$ & $0.60^{\mathrm{m}}$ & $0.44^{\circ}$ & 0.25 \\
\hline & $0 x$ (out) & & & & & & & & & 1.00 & -0.21 & -0.28 & $-0,67^{\prime \prime}$ & $-0,50^{\circ}$ & $0.58^{-1}$ & $0.45^{\circ}$ & 0.27 \\
\hline & $\mathrm{CO}$ (in) & & & & & & & & & & 1.00 & 0.37 & 0.39 & $.428^{\circ}$ & $-0.59^{* \prime}$ & $-0.54^{*}$ & -0.21 \\
\hline & $\mathrm{CO}$ (out) & & & & & & & & & & & 1.00 & $0.57^{* \prime}$ & $.548^{m+}$ & $-0.5 \mathrm{~g}^{\prime \prime}$ & $-0.56^{\prime \prime}$ & $-0,36$ \\
\hline \multirow{12}{*}{ 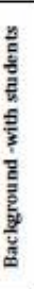 } & $\mathrm{PM}_{25}$ (in) & $0.92^{-1}$ & $0.60^{\circ \prime}$ & $0.55^{*}$ & -0.07 & 0.01 & $0.58^{\prime \prime}$ & $0.65^{\prime \prime}$ & 0.22 & 0.29 & 0.44 & $0.50^{\circ}$ & 0.21 & 0.22 & 0.40 & 0.08 & $-0,41$ \\
\hline & $\mathrm{PM}_{2 \mathrm{z}}$ (out) & 1.00 & $0.69^{* *}$ & 0.35 & -0.08 & -0.04 & $0.74^{* \prime}$ & $0.77^{\prime \prime}$ & 0.04 & 0.10 & $0.54^{*}$ & $0.47^{*}$ & 0.23 & 0.22 & 0.41 & 0.10 & $-0,47^{*}$ \\
\hline & $\mathrm{PM}_{25 \cdot \mathrm{n}}$ (in) & & 1.00 & $0.33^{*}$ & 0.19 & 0.31 & $0.72^{-*}$ & $0.71^{-\prime}$ & -0.14 & -0.10 & $0.71^{\prime \prime}$ & 0.44 & 0.35 & $0.50^{\circ}$ & -0.01 & $-0,41$ & $-0.54^{*}$ \\
\hline & $P_{2=10}$ (out) & & & 1.00 & -0.04 & 0.10 & 0.10 & 0.14 & 0.36 & 0.41 & -0.16 & 0.15 & 0.10 & 0.17 & 0.14 & -0.11 & -0.24 \\
\hline & TVOC(in) & & & & 1.00 & $0.95^{\prime \prime}$ & 0.19 & 0.28 & $-0.69^{-"}$ & $-0,64^{-\prime}$ & 0.27 & $0.49^{\circ}$ & $0.87^{* *}$ & $0.84^{*-}$ & $-0.86^{\prime \prime}$ & $-0.75^{*}$ & $-0.55^{*}$ \\
\hline & TVOC(out) & & & & & 1.00 & 0.17 & 0.27 & $-0.58^{*}$ & $-0.54^{*}$ & 0.25 & $0.58^{*}$ & $0.82^{\prime \prime}$ & $0.92^{-\prime}$ & $-0.86^{\prime \prime}$ & $-0.87^{* \prime}$ & $-0.59^{\prime \prime}$ \\
\hline & $\mathrm{CO}_{2}$ (in) & & & & & & 1.00 & $0.91^{\prime \prime}$ & -0.35 & $-0,30$ & $0.74^{-\prime}$ & 0.46 & 0,42 & 0.30 & 0.07 & -0.12 & $-0,40$ \\
\hline & $\mathrm{CO}_{2}$ (out) & & & & & & & 1.00 & -0.20 & $-0,16$ & $0.82^{\prime \prime}$ & $0.62^{*-}$ & 0,41 & 0.37 & 0.08 & -0.14 & $-0,48^{\circ}$ \\
\hline & $0_{3}$ (in) & & & & & & & & 1.00 & $0.96^{\prime \prime}$ & -0.17 & -0.27 & $-0.76^{\prime \prime}$ & $-0.59^{\mathrm{m}}$ & $0.70^{-2}$ & $0.52^{\circ}$ & 0.38 \\
\hline & 0 (out) & & & & & & & & & 1.00 & -0.14 & -0.23 & $-0.73^{\prime \prime}$ & $-0.53^{*}$ & $0.71^{-1}$ & $0.50^{\circ}$ & 0.39 \\
\hline & $\mathrm{CO}$ (in) & & & & & & & & & & 1.00 & 0.40 & 0.31 & 0.30 & 0.04 & -0.14 & .0 .35 \\
\hline & $\mathrm{CO}$ (out) & & & & & & & & & & & 1.00 & $0.51^{\circ}$ & $0.68^{\mathrm{m}}$ & -0.33 & $-0.54^{\circ}$ & $-0.47^{\circ}$ \\
\hline \multirow{12}{*}{$\frac{\text { E }}{2}$} & $\mathrm{PM}_{25}$ (in) & $0.97^{\prime \prime}$ & 0.80 & $0.98^{\prime \prime}$ & $0,93^{\prime \prime}$ & $0.96^{\prime \prime}$ & $0.97^{*}$ & $0,95^{\prime \prime}$ & -0.77 & $-0.99^{\prime \prime}$ & $0.92^{-\prime}$ & 0.38 & 0.04 & 0.79 & -0.36 & -0.70 & $-0,71$ \\
\hline & $\mathrm{PM}_{22}$ (out) & 1.00 & $0.89^{\circ}$ & $0.98^{* \prime}$ & $0.94^{-\prime}$ & $0.93^{* *}$ & $0.96^{\prime \prime}$ & $0.92^{-*}$ & $-0.82^{*}$ & $-0.98^{\prime \prime}$ & $0.89^{\circ}$ & 0.51 & 0.00 & 0.75 & -0.28 & -0.62 & -0.73 \\
\hline & $\mathrm{PM}_{2 \sin }$ (in) & & 1.00 & $0.85^{+}$ & $0.83^{\circ}$ & 0.75 & $0.83^{*}$ & 0.78 & $-0.93^{-1}$ & $-0.82^{*}$ & 0.70 & 0.59 & -0.16 & 0.60 & -0.01 & $-0,42$ & -0.59 \\
\hline & PM/2=10(out) & & & 1.00 & $0.98^{\prime \prime}$ & $0.98^{\prime \prime}$ & $0.98^{\prime \prime}$ & $0.91^{\prime \prime}$ & -0.80 & $-0,96^{\prime \prime}$ & $0,95^{\prime \prime}$ & 0.46 & 0.13 & $0.85^{\circ}$ & -0.41 & -0.75 & $-0,61$ \\
\hline & TVOC(in) & & & & 1.00 & $0.97^{*}$ & $0.95^{\prime \prime}$ & $0.84^{\circ}$ & -0.75 & $-0.89^{*}$ & $0.94^{-1}$ & 0.45 & 0.29 & $0.91^{-*}$ & -0.52 & $-0.81^{\circ}$ & -0.51 \\
\hline & TVOC(out) & & & & & 1.00 & $0.97^{* \prime}$ & $0.88^{\circ}$ & -0.71 & $-0.91^{\prime \prime}$ & $0.98^{\prime \prime}$ & 0.39 & 0.29 & $0.92^{\mathrm{*}}$ & -0.57 & $-0.85^{\circ}$ & -0.51 \\
\hline & $\mathrm{CO}_{2}$ (in) & & & & & & 1.00 & $0.95^{\prime \prime}$ & $-0.84^{*}$ & $-0,95^{\prime \prime}$ & $0,93^{\prime \prime}$ & 0.39 & 0.06 & $0.84^{*}$ & -0.37 & -0.74 & -0.57 \\
\hline & $\mathrm{CO}_{2}$ (out) & & & & & & & 1.00 & $-0.83^{\circ}$ & $-0,95^{\prime \prime}$ & $0.81^{\circ}$ & 0.20 & $-0,18$ & 0.69 & -0.16 & $-0,62$ & -0.68 \\
\hline & $0_{3}$ (in) & & & & & & & & 1.00 & $0.78^{\circ}$ & -0.65 & -0.44 & 0.34 & -0.54 & -0.10 & 0.39 & 0.48 \\
\hline & Orrout) & & & & & & & & & 1.00 & $-0.87^{*}$ & -0.39 & 0.06 & -0.71 & 0.25 & 0.61 & 0.78 \\
\hline & $\mathrm{CO}$ (in) & & & & & & & & & & 1.00 & 0.49 & 0.35 & $0.90^{\circ}$ & -0.64 & $-0.82^{\circ}$ & -0.45 \\
\hline & $\mathrm{CO}$ (out) & & & & & & & & & & & 1.00 & 0.10 & 0.26 & -0.15 & -0.04 & -0.29 \\
\hline
\end{tabular}

\section{Short-term health implications}

The most commonly reported symptoms that exceed $50 \%$ of the students' perception in both schools were difficulties in concentration (focusing) (78.5\%), drowsiness $86.7 \%$, heavy headed and dizziness $54.2 \%$, fatigue $84 \%$, feeling thirsty $86.1 \%$, handy dry, itching and red skin $89.4 \%$, feeling uncomfortable $59.6 \%$, heavy sweating $54.2 \%$, sneezing $73.1 \%$, irritated nose $56.9 \%$, nose congestion $73.1 \%$ and runny nose $54.2 \%$ as presented in Table 5. In Malaysia there was dearth of studies that investigated the SBS in schools' buildings, where all of studies were conducted in office buildings. By comparing the prevalence rates of SBS symptoms with other studies such as Juliana et al. (2009), Nur Fadilah and Juliana (2012) and Norhidayah et al. (2013), the results showed that the prevalence of SBS symptoms i.e. stuffy, runny nose; sinus; headache; itchy, dry and irritation eyes; difficulty in breath; and shortness of breath were significantly more prevalent amongst office workers and schools children. 
Volume4 : Issue 1, October, 2020

The higher SBS symptoms in Malaysian schools could be due to the fluctuations of temperature and humidity in occupied spaces, even in a building with an adequate fresh air supplies and low indoor air pollutants. The high indoor relative humidity was found to have direct and indirect effects on residential buildings, such as increasing the growth of mites, fungus, virus and bacteria which cause different health problems. In Salleh et al. (2013) study, which compares indoor relative humidity with annual absentees among school students in Malaysia, the results showed that the non-air-conditioning classrooms have higher absentee's rates of sickness as compared to the air-conditioned classrooms.

Table 5: The prevalence rate of health symptoms amongst students

\begin{tabular}{|l|c|c|c|}
\hline \multirow{2}{*}{$\begin{array}{l}\text { Health and uncomfortable } \\
\text { symptoms }\end{array}$} & \multicolumn{2}{|c|}{ At least once a week } & \multirow{2}{*}{\begin{tabular}{l} 
Palue \\
\cline { 2 - 3 }
\end{tabular}} \\
\cline { 2 - 4 } & Non-haze event & Haze event & \\
\hline Difficulties in focusing & 70.73 & 81.63 & 0.24 \\
\hline Drowsiness & 78.05 & 81.63 & 0.68 \\
\hline Breathing shortness & 4.08 & 17.07 & $\mathbf{0 . 0 5}$ \\
\hline Heavy headed and dizziness & 48.78 & 51.02 & 0.83 \\
\hline Headache & 28.57 & 36.59 & 0.42 \\
\hline Chest pain & 12.24 & 29.27 & $\mathbf{0 . 0 5}$ \\
\hline Fatigue & 75.61 & 75.51 & 0.99 \\
\hline Eye irritation & 32.65 & 41.46 & 0.39 \\
\hline Handy dry, itching and red skin & 67.35 & 80.49 & 0.16 \\
\hline Feeling uncomfortable & 53.66 & 65.31 & 0.27 \\
\hline Sneezing & 65.85 & 87.76 & $\mathbf{0 . 0 2}$ \\
\hline Irritated nose & 40.82 & 51.22 & 0.33 \\
\hline Nose congestion & 48.98 & 65.85 & 0.11 \\
\hline Runny nose & 48.78 & 44.9 & 0.72 \\
\hline Wheezing & 2.44 & 6.12 & 0.4 \\
\hline Get rid of phlegm several times & 8.16 & 21.95 & 0.08 \\
\hline
\end{tabular}

Moreover, the result indicated that, in most of the symptoms, there are no significant differences between non-haze and haze events. The only significant differences were in breathing shortness, chest pain and sneezing. This increased difference supports the fact that outdoor as well as indoor polluted air could influence the air quality indoors. 
Volume4 : Issue 1, October, 2020

\section{Conclusions}

This study analysed the impact of haze episodes on the indoor classrooms' environment in two different schools in Malaysia that are subject to frequent haze events. The results show that the indoor $\mathrm{PM}_{2.5}$ and $\mathrm{PM}_{2.5-10}$ were affected mainly by the outdoor PMs on both non-haze days and haze days. On non-haze days (background period), the daily averages of outdoor PMs concentrations fell within a narrow range with small variations. However, on haze days, the levels of hourly $\mathrm{PM}_{2.5}(30.04 \pm 7.82 \mu \mathrm{g} / \mathrm{m} 3$ and $28.07 \pm 4.66 \mu \mathrm{g} / \mathrm{m} 3)$ for indoor and outdoor, respectively) significantly increased well beyond WHO guidelines $\left(25 \mu \mathrm{g} / \mathrm{m}^{3}\right)$. The average concentrations of TVOC $(0.91 \pm 0.30 \mathrm{ppm}), \mathrm{O}_{3}$ $(0.01 \pm 0.08 \mathrm{ppm}), \mathrm{CO}(0.06 \pm 0.12 \mathrm{ppm})$ and $\mathrm{CO}_{2}(498.40 \pm 51.6 \mathrm{ppm})$ in classrooms were found to be lower than the stipulated values set by the Malaysian DOSH and no significant differences in concentrations recorded in the different sampling periods.

The average indoor and outdoor $\mathrm{PM}_{2.5} / \mathrm{PM}_{10}$ ratios in classrooms ranged from $0.43 \pm 0.13$ to $0.66 \pm 0.08$ and from $0.47 \pm 0.17$ to $0.70 \pm 0.07$, respectively. This indicates that fine particlulates $(<2.5 \mu \mathrm{m})$ are the dominating fraction in particulate matter in the three monitoring periods. $\mathrm{PM}_{2.5-10}$ and $\mathrm{PM}_{2.5}$ concentrations reached a maximum during morning hours in the beginning of the schools in all of three periods followed by a unimodal pattern peak between 09:00 and 10:00 a.m. for $\mathrm{PM}_{2.5-10}$. The results of this study indicated that the concentration of $\mathrm{PM}_{2.5-10}$ is influenced by the students' movements which may promote coarser PMs resuspension or delay the deposition process.

The I/O ratio values were found to be influenced by the influence of outdoor sources for all monitoring pollutants during the three periods. The results show that the $\mathrm{I} / \mathrm{O}$ ratios of $\mathrm{PM}_{2.5-10}$ are higher than that of $\mathrm{PM}_{2.5}$, which is due to higher indoor emission source of coarse particulates than fine particles. There was a strong correlation $(\mathrm{p}<0.01)$ between outdoor and indoor concentrations during haze and non-haze events for pollutants. This study, thus, demonstrates the 
Volume4 : Issue 1, October, 2020

impact of haze events on indoor air quality in school classrooms. It is evident that further studies should be implemented in other schools, considering different localities such as rural, suburban and industrial areas during haze events for better protection of human health and life quality. 
Volume4 : Issue 1, October, 2020

\section{References}

1. Abidin, E. Z., Semple, S., Rasdi, I., Ismail, S. N. S., \& Ayres, J. G. (2014). The relationship between air pollution and asthma in Malaysian schoolchildren. Air Quality, Atmosphere \& Health, 7(4), 421-432.

2. Abt, E., Suh, H. H., Catalano, P., \& Koutrakis, P. (2000). Relative contribution of outdoor and indoor particle sources to indoor concentrations. Environmental science \& technology, 34(17), 3579-3587.

3. Afroz, R., Hassan, M. N., \& Ibrahim, N. A. (2003). Review of air pollution and health impacts in Malaysia. Environmental research, 92(2), 71-77.

4. Almeida, S. M., Canha, N., Silva, A., do Carmo Freitas, M., Pegas, P., Alves, C., ... $\&$ Pio, C. A. (2011). Children exposure to atmospheric particles in indoor of Lisbon primary schools. Atmospheric Environment, 45(40), 7594-7599.

5. Alshitawi, M., Awbi, H., \& Mahyuddin, N. (2009). Particulate matter mass concentration (PM10) under different ventilation methods in classrooms. International Journal of Ventilation, 8(2), 93-108.

6. Andersson, K. (1998). Epidemiological approach to indoor air problems. Indoor air, 8(S4), 32-39.

7. Anwar, A., Juneng, L., Othman, M. R., \& Latif, M. T. (2010). Correlation between hotspots and air quality in Pekanbaru, Riau, Indonesia in 2006-2007. Sains Malaysiana, 39(2), 169-174.

8. Azmi, S. Z., Latif, M. T., Ismail, A. S., Juneng, L., \& Jemain, A. A. (2010). Trend and status of air quality at three different monitoring stations in the Klang Valley, Malaysia. Air Quality, Atmosphere \& Health, 3(1), 53-64.

9. Behera, S. N., Betha, R., Huang, X., \& Balasubramanian, R. (2015). Characterization and estimation of human airway deposition of size-resolved particulate-bound trace elements during a recent haze episode in Southeast Asia. Environmental Science and Pollution Research, 22(6), 4265-4280.

10. Betha, R., Pradani, M., Lestari, P., Joshi, U. M., Reid, J. S., \& Balasubramanian, R. (2013). Chemical speciation of trace metals emitted from Indonesian peat fires for health risk assessment. Atmospheric Research, 122, 571-578.

11. Blondeau, P., Iordache, V., Poupard, O., Genin, D., \& Allard, F. (2005). Relationship between outdoor and indoor air quality in eight French schools. Indoor air, 15(1), 212.

12. Chaloulakou, A., \& Mavroidis, I. (2002). Comparison of indoor and outdoor concentrations of $\mathrm{CO}$ at a public school. Evaluation of an indoor air quality model. Atmospheric Environment, 36(11), 1769-1781.

13. Chen, C., \& Zhao, B. (2011). Review of relationship between indoor and outdoor particles: I/O ratio, infiltration factor and penetration factor. Atmospheric Environment, 45(2), 275-288.

14. Chew, F. T., Ooi, B. C., Hui, J. K. S., Saharom, R., Goh, D. Y. T., \& Lee, B. W. (1995). Singapore's haze and acute asthma in children. The Lancet, 346(8987), 1427. 
Volume4 : Issue 1, October, 2020

15. Chithra, V. S., \& Nagendra, S. S. (2012). Indoor air quality investigations in a naturally ventilated school building located close to an urban roadway in Chennai, India. Building and Environment, 54, 159-167.

16. Diapouli, E., Chaloulakou, A., \& Spyrellis, N. (2007). Indoor and outdoor particulate matter concentrations at schools in the Athens area. Indoor and Built Environment, 16(1), 55-61.

17. Diette, G. B., Hansel, N. N., Buckley, T. J., Curtin-Brosnan, J., Eggleston, P. A., Matsui, E. C., ... \& Breysse, P. N. (2007). Home indoor pollutant exposures among inner-city children with and without asthma. Environmental Health Perspectives, 115(11), 1665-1669.

18. Dominick, D., Juahir, H., Latif, M. T., Zain, S. M., \& Aris, A. Z. (2012). Spatial assessment of air quality patterns in Malaysia using multivariate analysis. Atmospheric environment, 60, 172-181.

19. DOSH 2010. Code of Practice on Indoor Air Quality. Department of Safety and Health: Ministry of Human Resources Malaysia.

20. Elbayoumi, M., Ramli, N. A., \& Yusof, N. F. F. M. (2015). Spatial and temporal variations in particulate matter concentrations in twelve schools environment in urban and overpopulated camps landscape. Building and Environment, 90, 157-167.

21. Elbayoumi, M., Ramli, N. A., Yusof, N. F. F. M., \& Al Madhoun, W. (2013). Spatial and seasonal variation of particulate matter (PM10 and PM2. 5) in Middle Eastern classrooms. Atmospheric environment, 80, 389-397.

22. Emmanuel, S. C. (2000). Impact to lung health of haze from forest fires: the Singapore experience. Respirology, 5(2), 175-182.

23. Ferro, A. R., Kopperud, R. J., \& Hildemann, L. M. (2004). Source strengths for indoor human activities that resuspend particulate matter. Environmental science \& technology, 38(6), 1759-1764.

24. Fromme, H., Twardella, D., Dietrich, S., Heitmann, D., Schierl, R., Liebl, B., \& Rüden, H. (2007). Particulate matter in the indoor air of classrooms - exploratory results from Munich and surrounding area. Atmospheric Environment, 41(4), 854866.

25. Habil, M., Massey, D. D., \& Taneja, A. (2013). Exposure of children studying in schools of India to PM levels and metal contamination: sources and their identification. Air Quality, Atmosphere \& Health, 6(3), 575-587.

26. Hänninen, O., Hoek, G., Mallone, S., Chellini, E., Katsouyanni, K., Gariazzo, C., \& Jantunen, M. (2011). Seasonal patterns of outdoor PM infiltration into indoor environments: review and meta-analysis of available studies from different climatological zones in Europe. Air Quality, Atmosphere \& Health, 4(3-4), 221-233.

27. Hashim, J. H., Hashim, Z., \& Abidin, A. Z. (1996). Relationships between Visibility and Selected Air Pollutants in the Klang Valley. Akademika, 49(1).

28. Hassanvand, M. S., Naddafi, K., Faridi, S., Arhami, M., Nabizadeh, R., Sowlat, M. H., ... \& Gholampour, A. (2014). Indoor/outdoor relationships of PM10, PM2. 5, and PM1 mass concentrations and their water-soluble ions in a retirement home and a school dormitory. Atmospheric Environment, 82, 375-382. 
Volume4 : Issue 1, October, 2020

29. Ismail, M., Sofian, N. Z. M., \& Abdullah, A. M. (2010). Indoor air quality in selected samples of primary schools in Kuala Terengganu, Malaysia. Environment Asia, 3(103), e108.

30. Jacobson, M. Z. (2004). The short-term cooling but long-term global warming due to biomass burning. Journal of Climate, 17(15), 2909-2926.

31. Janssen, N. A., Hoek, G., Brunekreef, B., \& Harssema, H. (1999). Mass concentration and elemental composition of PM10 in classrooms. Occupational and Environmental Medicine, 56(7), 482-487.

32. Jayachandran, S. (2009). Air quality and early-life mortality evidence from Indonesia's wildfires. Journal of Human resources, 44(4), 916-954.

33. Kamaruzzaman, S. N., \& Razak, R. A. (2011). Measuring indoor air quality performance in Malaysian government kindergarten. Journal of Building Performance, 2(1).

34. Latif, M. T., Yong, S. M., Saad, A., Mohamad, N., Baharudin, N. H., Mokhtar, M. B., \& Tahir, N. M. (2014). Composition of heavy metals in indoor dust and their possible exposure: a case study of preschool children in Malaysia. Air Quality, Atmosphere \& Health, 7(2), 181-193.

35. Madureira, J., Alvim-Ferraz, M. C. M., Rodrigues, S., Gonçalves, C., Azevedo, M. C., Pinto, E., \& Mayan, O. (2009). Indoor air quality in schools and health symptoms among Portuguese teachers. Human and Ecological Risk Assessment, 15(1), 159169.

36. Makhtar, N. K., Ismail, A. R., Jusoh, N., \& Puvanasvaran, A. P. (2010). Thermal comfort in technical school: Physical measurement approach. In National Conference in Mechanical Engineering Research and Postgraduate Studies, Pahang, Malaysia (pp. 755-761).

37. Mathew, J., Goyal, R., Taneja, K. K., \& Arora, N. (2015). Air pollution and respiratory health of school children in industrial, commercial and residential areas of Delhi. Air Quality, Atmosphere \& Health, 8(4), 421-427.

38. Mizoue, T., Reijula, K., \& Andersson, K. (2001). Environmental tobacco smoke exposure and overtime work as risk factors for sick building syndrome in Japan. American Journal of Epidemiology, 154(9), 803-808.

39. MMD. 2013. General Climate of Malaysia [Online]. Malaysia. Available: http://www.met.gov.my/index.php?option=com_content\&task=view\&id=75\&Itemi $\mathrm{d}=1089$.

40. Mustapha, A. A., Ayop, S. M., Ahmad, M. K., \& Ismail, F. (2008). A thermal comfort study in naturally ventilated school building in Malaysia.

41. Nichol, J. (1998). Smoke haze in Southeast Asia: A predictable recurrence. Atmospheric environment (1994), 32(14-15), 2715-2716.

42. Nordström, K., Norbäck, D., \& Akselsson, R. (1994). Effect of air humidification on the sick building syndrome and perceived indoor air quality in hospitals: a four month longitudinal study. Occupational and environmental medicine, 51(10), 683-688.

43. Norhidayah, A., Chia-Kuang, L., Azhar, M. K., \& Nurulwahida, S. (2013). Indoor air quality and sick building syndrome in three selected buildings. Procedia Engineering, 53(0), 93-98. 
Volume4 : Issue 1, October, 2020

44. Nur Fadilah, R., \& Juliana, J. (2012). Indoor air quality (IAQ) and sick buildings syndrome (SBS) among office workers in new and old building in Universiti Putra Malaysia, Serdang. Health and the Environment Journal, 3(2), 98-109.

45. Othman, J., Sahani, M., Mahmud, M., \& Ahmad, M. K. S. (2014). Transboundary smoke haze pollution in Malaysia: Inpatient health impacts and economic valuation. Environmental Pollution, 189, 194-201.

46. Pavagadhi, S., Betha, R., Venkatesan, S., Balasubramanian, R., \& Hande, M. P. (2013). Physicochemical and toxicological characteristics of urban aerosols during a recent Indonesian biomass burning episode. Environmental Science and Pollution Research, 20(4), 2569-2578.

47. Payus, C., Abdullah, N., \& Sulaiman, N. (2013). Airborne particulate matter and meteorological interactions during the haze period in Malaysia. International Journal of Environmental Science and Development, 4(4), 398.

48. Pegas, P. N., Evtyugina, M. G., Alves, C. A., Nunes, T., Cerqueira, M., Franchi, M., ... \& Freitas, M. D. C. (2010). Outdoor/indoor air quality in primary schools in Lisbon: a preliminary study. Quimica nova, 33(5), 1145-1149.

49. Razali, N. Y. Y., Latif, M. T., Dominick, D., Mohamad, N., Sulaiman, F. R., \& Srithawirat, T. (2015). Concentration of particulate matter, $\mathrm{CO}$ and $\mathrm{CO} 2$ in selected schools in Malaysia. Building and environment, 87, 108-116.

50. Reid, J. S., Hyer, E. J., Johnson, R. S., Holben, B. N., Yokelson, R. J., Zhang, J., ... \& Holz, R. E. (2013). Observing and understanding the Southeast Asian aerosol system by remote sensing: An initial review and analysis for the Seven Southeast Asian Studies (7SEAS) program. Atmospheric Research, 122, 403-468.

51. Sahani, M., Zainon, N. A., Mahiyuddin, W. R. W., Latif, M. T., Hod, R., Khan, M. F., ... \& Chan, C. C. (2014). A case-crossover analysis of forest fire haze events and mortality in Malaysia. Atmospheric Environment, 96, 257-265.

52. Salleh, N. M., Kamaruzzaman, S. N., Sulaiman, R., \& Darus, F. M. (2013). Associate Between Indoor Relative Humidity and Absenteeism at Refurbished Pre-Schools in Malaysia. Advanced Science Letters, 19(10), 2999-3003.

53. Sillanpää, M., Saarikoski, S., Hillamo, R., Pennanen, A., Makkonen, U., Spolnik, Z., ... \& Salonen, R. O. (2005). Chemical composition, mass size distribution and source analysis of long-range transported wildfire smokes in Helsinki. Science of the total environment, 350(1-3), 119-135.

54. Siti, H. I., \& Baba, M. D. (2010). Indoor air quality issues for non-industrial work place. International Journal of Research and Reviews in Applied Sciences, 5(3), 235244.

55. Sundarambal, P., Balasubramanian, R., Tkalich, P., \& He, J. (2010). Impact of biomass burning on ocean water quality in Southeast Asia through atmospheric deposition: field observations. Atmospheric Chemistry and Physics, 10(23), 1132311336.

56. Sundarambal, P., Balasubramanian, R., Tkalich, P., \& He, J. (2010). Impact of biomass burning on ocean water quality in Southeast Asia through atmospheric deposition: field observations. Atmospheric Chemistry and Physics, 10(23), 1132311336. 
Volume4 : Issue 1, October, 2020

57. Syazwan Aizat, I., Juliana, J., Norhafizalina, O., Azman, Z. A., \& Kamaruzaman, J. (2009). Indoor air quality and sick building syndrome in Malaysian buildings. Glob J Health Sci, 1(2), 126-136.

58. USEPA. 2012. Indoor Air Quality, tools for schools. [Online]. Enviromnetal Protection Agency (EPA). Available: http://www.epa.gov/iaq/schools/ [Accessed 7 April 2012.

59. Ward, D. E. (1990). Factors influencing the emissions of gases and particulate matter from biomass burning. In Fire in the Tropical Biota (pp. 418-436). Springer, Berlin, Heidelberg.

60. WHO 2005. WHO Air Quality Guidelines Global Update 2005. Bonn, Germany: World Health Organization (WHO).

61. WHO 2011. Methods for monitoring indoor air quality in schools Bonn. Germany World Health Organization (WHO).

62. Xu, J., Tai, X., Betha, R., He, J., \& Balasubramanian, R. (2015). Comparison of physical and chemical properties of ambient aerosols during the 2009 haze and nonhaze periods in Southeast Asia. Environmental geochemistry and health, 37(5), 831841.

63. Zhao, L., Chen, C., Wang, P., Chen, Z., Cao, S., Wang, Q., \& Lu, B. (2015). Influence of atmospheric fine particulate matter (PM2. 5) pollution on indoor environment during winter in Beijing. Building and Environment, 87, 283-291.

64. Zock, J. P., Jarvis, D., Luczynska, C., Sunyer, J., Burney, P., \& European Community Respiratory Health Survey. (2002). Housing characteristics, reported mold exposure, and asthma in the European Community Respiratory Health Survey. Journal of Allergy and Clinical Immunology, 110(2), 285-292. 